\title{
Proteome-wide characterization and biomarker identification of intracranial aneurysm
}

Tanavi Sharma ${ }^{1}$, Keshava K. Datta ${ }^{2}$, Munish Kumar ${ }^{1}$, Gourav Dey ${ }^{2}$, Aafaque Ahmad Khan ${ }^{2}$, Kiran Kumar Mangalaparthi ${ }^{2}$, Poonam Saharan ${ }^{1}$, Shobia C. ${ }^{1}$, Ashish Aggarwal ${ }^{3}$, Navneet Singla $^{3}$, Sujata Ghosh ${ }^{4}$, Amit Rawat ${ }^{5}$, Sivashanmugam Dhandapani ${ }^{3}$, Pravin Salunke ${ }^{3}$, Rajesh Chhabra $^{3}$, Dalbir Singh ${ }^{6}$, Aastha Takkar ${ }^{7}$, Sunil K. Gupta ${ }^{3}$, T. S. Keshava Prasad ${ }^{2,8}$, Harsha Gowda $^{2,8,9}$, Akhilesh Pandey ${ }^{2,9,10,11^{*}}$ and Hemant Bhagat ${ }^{*}$

${ }^{1}$ Division of Neuroanaesthesia, Department of Anaesthesia and Intensive Care, Post Graduate Institute of Medical Education and Research, Chandigarh 160012, India

${ }^{2}$ Institute of Bioinformatics, International Tech Park, Bangalore 560066, India

${ }^{3}$ Department of Neurosurgery, Post Graduate Institute of Medical Education and Research, Chandigarh 160012, India

${ }^{4}$ Department of Experimental Medicine and Biotechnology, Post Graduate Institute of Medical Education and Research, Chandigarh 160012, India

${ }^{5}$ Pediatric Allergy and Immunology Unit, Advanced Pediatrics Centre, PGIMER, Chandigarh 160012, India

${ }^{6}$ Department of Forensic Medicine, Post Graduate Institute of Medical Education and Research, Chandigarh 160012, India

${ }^{7}$ Department of Neurology, Post Graduate Institute of Medical Education and Research, Chandigarh 160012, India

${ }^{8}$ Center for Systems Biology and Molecular Medicine, Yenepoya Research Centre, Yenepoya University, Mangalore, India

${ }^{9}$ Manipal Academy of Higher Education (MAHE), Manipal, India.

${ }^{10}$ Department of Laboratory Medicine and Pathology, Rochester, MN, 55905, USA;

${ }^{11}$ Center for Individualized Medicine, Mayo Clinic, Rochester, MN, 55905, USA

*To whom correspondence should be addressed:

Hemant Bhagat, M.D., D.M.

Professor, Division of Neuroanaesthesia

Department of Anaesthesia and Intensive Care

PGIMER, Chandigarh - 160012

E-mail: bhagat.hemant@pgimer.edu.in

And

Akhilesh Pandey, M.D., Ph.D.

Center for Individualized Medicine,

Mayo Clinic, Rochester, MN, 55905, USA 
bioRxiv preprint doi: https://doi.org/10.1101/725473; this version posted August 9, 2019. The copyright holder for this preprint (which was not certified by peer review) is the author/funder, who has granted bioRxiv a license to display the preprint in perpetuity. It is made available under aCC-BY-NC-ND 4.0 International license.

\section{E-mail: Pandey.Akhilesh@mayo.edu}




\begin{abstract}
The scientific basis of intracranial aneurysm (IA) formation, its rupture and further development of cerebral vasospasm remains incompletely understood. Deciphering the molecular mechanisms underlying these events will lead to identification of early detection biomarkers and in turn, improved treatment outcomes. Aberrant protein expression may drive structural alterations of vasculature found in IA. To unravel these aberrations, we performed untargeted, global, quantitative proteomic analysis of aneurysm tissue and serum from patients with IA. Samples were derived from patients of three clinical sub groups-1) unruptured aneurysm 2) ruptured aneurysm without vasospasm 3) ruptured aneurysm who developed vasospasm. A total of 937 and 294 proteins were identified in aneurysm tissue and serum samples respectively. Several proteins that are known to maintain the structural integrity of vasculature were found to be dysregulated. ORM1, a glycoprotein, was significantly upregulated in both the aneurysm tissue and serum samples of unruptured IA patients. We employed a larger cohort of patients and validated ORM1 as a potential biomarker for screening of unruptured aneurysm using ELISA. Samples from ruptured aneurysm with vasospasm showed significant upregulation of MMP9 as compared to ruptured aneurysm without vasospasm. Using a cohort of ruptured aneurysm patients with and without vasospasm, we validated MMP9 as a potential biomarker for vasospasm. This study reveals pathophysiology underlying different clinical sub groups of IA and also suggests potential biomarkers.
\end{abstract}




\section{Introduction}

Intracranial aneurysm (IA) is a pathological dilation of intracranial artery that is characterized by focal deterioration of the vessel wall that involves loss of internal elastic lamina, disruption of media and disintegration of adventitia and extracellular matrix of the artery (Frosen et al., 2004, Nakajima et al., 2000, Rajesh et al., 2004). IA may be either familial or sporadic and is found to affect 3.2\% of the general population (Vlak et al., 2011). Patients who harbor IA are usually not detected and are manifested only once the aneurysm ruptures, leading to intracranial bleed and elevated intracranial pressure (Zoerle et al., 2015). The consequences of rupture of an aneurysm are both on the cerebral and systemic physiology leading to multi system changes (Chen et al., 2014). Despite technological advances in the management for prevention of rebleeding, the blood present in the intracranial space itself acts as a trigger for various inflammatory pathways leading to delayed cerebral ischemia and worsening the outcome of the patients or further adding to ongoing neurological insults (Archavlis and Carvi Y Nievas et al., 2013, Chaichana et al., 2010). Though the clinical spectrum of the disease has been established, mechanisms and pathophysiology of disease initiation and progression, i.e. aneurysm formation, rupture and subsequent development of cerebral vasospasm, are largely unknown until date.

There are no molecular biomarkers that can be used for early detection of intracranial aneurysm. Moreover, the patients at risk of aneurysmal rupture and those who can subsequently develop cerebral vasospasm cannot be predicted. A few targets for disease management have shown promise but have not been able to reduce the disease burden significantly. It is intriguing that despite various scientific and technological advances in research and clinical management, till date it has not been possible to reduce the burden of the disease which carries mortality of $30 \%$ and morbidity of 50\% (Findlay et al., 2016). Various studies directed towards deciphering the pathophysiology as well as to guide management of disease have not yielded beneficial results. Therefore, a more holistic understanding of the disease spectrum is the need of the hour. Patients who harbor IA are not victims of a single disease but a disease spectra that can range from an unruptured IA to aneurysmal subarachnoid hemorrhage (aSAH), hemorrhagic stroke and may further progress to cerebral ischemia (ischemic stroke). In this context, it is important to unravel the molecular basis of IA. Structural changes that are seen during aneurysm formation and rupture appear to be related to proteins as demonstrated in a few studies targeting single proteins (Connolly et al., 1997, Gaetani et al., 1997). Therefore, we envisaged a global, untargeted proteomic study of entire disease spectrum of patients with IA using both aneurysm tissue and serum samples. We employed a mass spectrometry (MS)-based quantitative proteomics approach to study protein based molecular alterations in patients with IA. To the best of our knowledge, this is the first report regarding whole proteome characterization of the entire disease spectrum in IA.

\section{Materials and Methods}

The study was conducted at Post Graduate Institute of Medical Education and Research, Chandigarh and the Institute of Bioinformatics, Bangalore, India. The study was designed to unravel the proteomic differences in patients who harbor cerebral aneurysm in comparison to those who do not. Further, the study looked into the difference in protein expression between unruptured aneurysm and those who rupture and subsequently those who develop cerebral vasospasm. Consequently, four groups of patients were studied - a) control group (Group C), b) unruptured aneurysm (Group T1), c) ruptured aneurysm without vasospasm (Group T2) 
and d) ruptured aneurysm with vasospasm (Group T3). This study was approved by Institutional Ethics Committee PGIMER, Chandigarh (IEC- 07/2015-268). Subjects were enrolled in the study only after obtaining an informed consent from the subject or their next of kin. Aneurysm tissue and blood samples were collected from the subjects of the four groups.

\section{Aneurysm-Tissue Samples}

Aneurysmal wall tissue samples were collected from each test group (T1, T2 and T3) during surgery. For controls, (Group C), intracranial artery tissue was collected from the circle of Willis of those subjects undergoing autopsy and with no evidence of intracranial aneurysm. Samples were collected within $4-6 \mathrm{~h}$ following death. Tissue samples were collected in plain vials following washing with normal saline. Tissue samples were then stored at $-80^{\circ} \mathrm{C}$ until further use.

\section{Serum Samples}

For test groups, blood samples were collected prior to surgery, before giving any anaesthetic agent, or any treatment. For controls, blood samples were collected from the subjects with negative angiography for any kind of cerebrovascular dysfunction. These were the subjects who underwent angiography for cerebrovascular evaluation and had no cerebrovascular disorder on angiography.

Blood samples $(5 \mathrm{ml})$ were collected in plain vials and were allowed to coagulate for $45 \mathrm{~min}$ at $37^{\circ} \mathrm{C}$ and centrifuged $\left(3000 \mathrm{rpm}\right.$ for $\left.15 \mathrm{~min}, 4^{\circ} \mathrm{C}\right)$ to obtain serum (supernatant). All serum samples were stored at $-80^{\circ} \mathrm{C}$ until further use.

\section{Study Design}

Study was divided into two phases - Discovery Phase and Validation Phase.

\section{Discovery Phase}

In discovery phase, differentially regulated proteins were identified in aneurysm tissue and serum samples using untargeted high resolution mass spectrometry-based proteomics. We collected a total of 20 tissue samples and 20 serum samples for discovery phase analysis. Out of them, five tissue/serum samples were collected in each test group (T1, T2 and T3) and control group (C).

\section{Validation Phase}

In the validation phase, candidate biomarkers obtained from mass spectrometry data analysis were confirmed on a large cohort of samples. For validation phase, a total of 78 serum samples were collected and processed in four groups i.e. C, T1, T2 and T3. For screening marker of unruptured IA, 13 serum samples in Group C and 13 in Group T1 were collected. For validation of candidate molecule for vasospasm prediction, 26 serum samples in Group T2 and 26 in Group T3 were collected. For all the test groups, patients with unruptured IA (T1), ruptured IA without vasospasm (T2) and ruptured IA with vasospasm were diagnosed based on CT scan and angiographic examination. For controls, subjects with no evidence of intracranial aneurysm on autopsy or angiographic examination were included for the study. 


\section{Sample preparation for LC-MS3 analysis}

Mass spectrometry based quantitative proteomic analyses of aneurysm tissue and serum samples of groups C, T1, T2, and T3 were carried out as follows (Fig. 1).

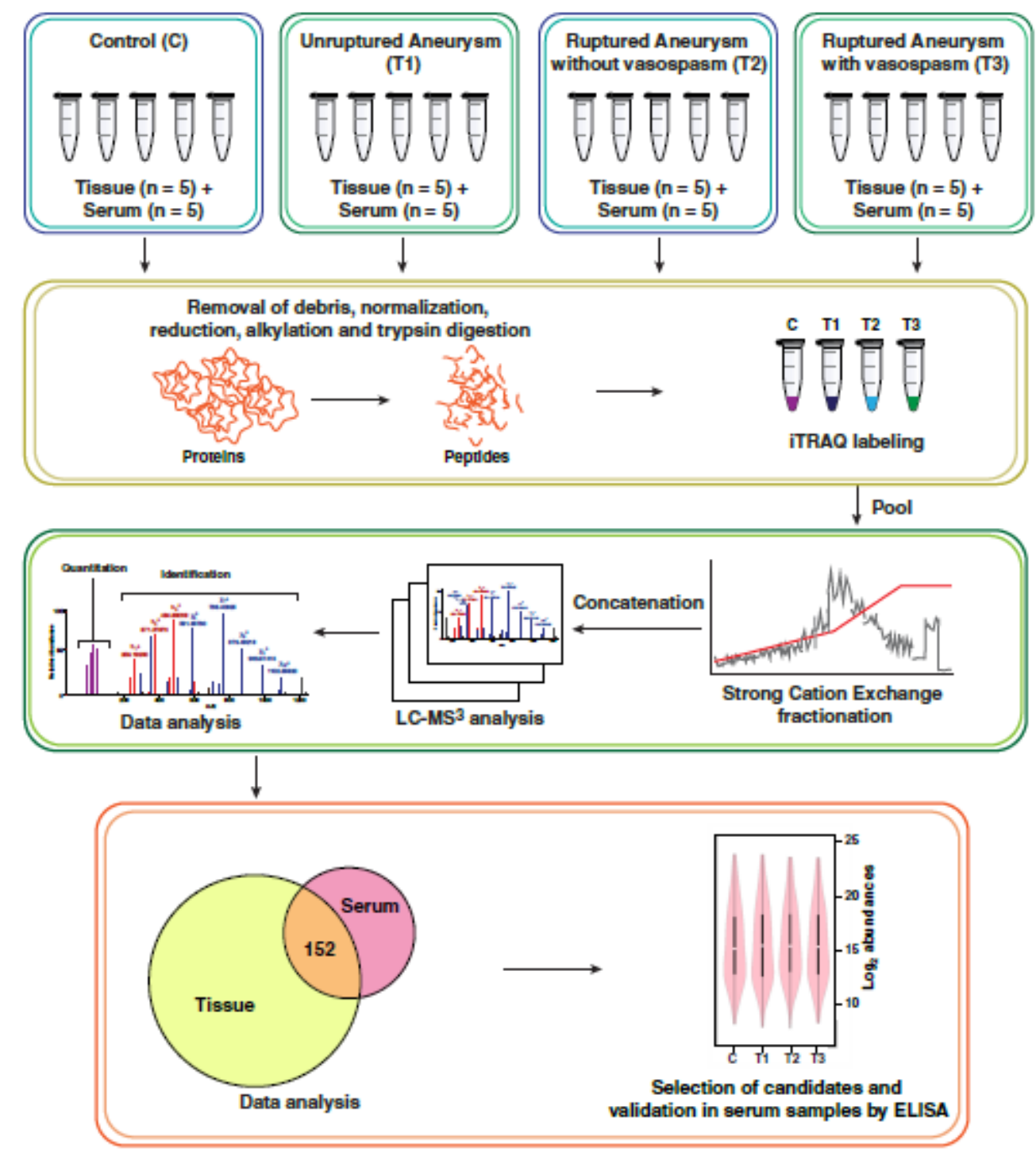

Figure 1: Overview of the study

\section{Protein Extraction}

Equal masses of five tissue samples from each group i.e. C, T1, T2 and T3 were pooled and disrupted in liquid nitrogen using a hand-held disruptor. Subsequently, these were homogenized in lysis buffer $(0.5 \%$ SDS, $100 \mathrm{mM}$ triethyl ammonium bicarbonate (TEAB)); centrifuged and clear supernatant was separated. Protein estimation was carried out using bicinchoninic acid (BCA) assay (Pierce, Waltham, MA;(Smith et al., 1985).

For serum samples, total protein was measured by BCA assay in groups C, T1, T2 and T3. Equal amount of proteins from five individual samples were pooled in each group. Serum samples were then depleted of highly abundant serum proteins using Human multiple affinity 
bioRxiv preprint doi: https://doi.org/10.1101/725473; this version posted August 9, 2019. The copyright holder for this preprint (which was not certified by peer review) is the author/funder, who has granted bioRxiv a license to display the preprint in perpetuity. It is made available under aCC-BY-NC-ND 4.0 International license.

removal system-14 (MARS-14) column (Agilent Technologies, CA) as per manufacturers' instructions.

\section{Trypsin digestion}

Equal amount of proteins from each group were reduced using Tris (2-carboxyethyl) phosphine (TCEP) at $60^{\circ} \mathrm{C}$ for $1 \mathrm{~h}$. Reduction was followed by alkylation using methylmethanethiosulfonate (MMTS) at room temperature for 10min. Trypsin (modified sequencing grade; Promega, Madison, WI) was added (enzyme: protein = 1:20) to the samples and digestion was carried out at $37^{\circ} \mathrm{C}$ for $16 \mathrm{~h}$. Reaction was quenched by acidifying the tryptic peptides with formic acid.

\section{iTRAQ labeling and fractionation}

4-plex iTRAQ was used to label the peptides as per manufacturers' instructions. Peptides obtained from Group C were labeled with isobaric group 114 while peptides for groups T1, T2, T3 were labeled with 115, 116 and 117 respectively (Fig.1). Labeled samples were pooled and subjected to strong cation exchange chromatography-based fractionation. A polystyrene-divinyl benzene copolymer modified with sulfonic acid Stage Tips (Empore Solid Phase Extraction Disk) were used as columns for fractionation. Sample digest containing iTRAQ labeled pooled peptides was reconstituted in $70 \mu \mathrm{l}$ of $1 \%$ TFA and fractionated into 6 fractions with in - house prepared columns (Deeb et al., 2015). The fractions were dried, reconstituted in $0.1 \%$ formic acid and desalted using C18 Stage Tips.

\section{LC-MS3 analysis}

iTRAQ labeled fractions were analyzed on Orbitrap Fusion Tribrid mass spectrometer (Thermo Scientific, Bremen, Germany) interfaced with Proxeon Easy-nLC II system (Thermo Scientific, Bremen, Germany). Each fraction was first loaded on a $2 \mathrm{~cm}$ long trap column packed with MagicC18AQ (Michrom Bioresources, Inc., Auburn, CA, USA). A linear gradient of $5 \%$ to $30 \%$ of solvent B (95\% acetonitrile, $0.1 \%$ formic acid) at a flow rate of $300 \mathrm{nl} / \mathrm{min}$ was used on an analytical column $(75 \mu \mathrm{m} \times 20 \mathrm{~cm}$, Magic C18AQ) for separation of peptides. Total run time was set to $120 \mathrm{~min}$. Each fraction was analyzed three times. Mass spectrometer was operated on data dependent acquisition mode. Scan range was set on 400-1600 m/z. Orbitrap mass analyzer was operated at a mass resolution of 120,000 at MS level; For MS/MS and MS/MS/MS levels resolution was set to 30,000 and 60,000 respectively. Most intense precursor ions were selected and fragmented using higher energy collision dissociation (HCD).

\section{Data Analysis}

The data acquired were searched against Human RefSeq81 protein database. The searches were performed using SEQUEST and MASCOT through Proteome Discoverer (Version 2.1) software suite (Thermo Scientific, Bremen, Germany). The search parameters included trypsin as the proteolytic enzyme with one missed cleavage and oxidation of methionine as a dynamic modification. Static modifications were carbamidomethylation of cysteine and iTRAQ label at N-terminus of the peptide and lysine. Precursor and fragment ion mass tolerance were set at $10 \mathrm{ppm}$ and $0.05 \mathrm{Da}$ respectively. False discovery rate (FDR) was calculated using a target-decoy strategy and 1\% FDR was applied at the peptide level. 
bioRxiv preprint doi: https://doi.org/10.1101/725473; this version posted August 9, 2019. The copyright holder for this preprint (which was not certified by peer review) is the author/funder, who has granted bioRxiv a license to display the preprint in perpetuity. It is made available under aCC-BY-NC-ND 4.0 International license.

Quantification was carried out using the reporter ion quantifier node for iTRAQ available in Proteome Discoverer.

\section{Data Availability}

The mass spectrometry proteomics data have been deposited to the ProteomeXchange Consortium via the Pride partner repository with the dataset identifier PXD013442.

\section{Enzyme linked immunosorbent assay (ELISA)}

ELISA kits were procured from Cloud-Clone Corporation, USA. ELISA-based validation of selected candidate proteins was carried out as per manufacturers' instructions. Briefly, $100 \mu 1$ of diluted serum samples, standard dilutions and blank were added to appropriate wells. ELISA plate was sealed with the help of sealer and incubated for $60 \mathrm{~min}$ at $37^{\circ} \mathrm{C}$. Liquid was decanted off from each well after incubation. Detection reagent A $(100 \mu 1)$ was then added to each well. Again, the plate was sealed and incubated for $60 \mathrm{~min}$ at $37^{\circ} \mathrm{C}$. Post incubation, wells were washed thrice with wash buffer and liquid was completely decanted off. $100 \mu \mathrm{l}$ of detection reagent $\mathrm{B}$ was added to each well and plate was incubated at $37^{\circ} \mathrm{C}$ for $30 \mathrm{~min}$. The plate was washed three times with wash buffer. $90 \mu 1$ of substrate solution was then added and plate was incubated for $15 \mathrm{~min}$ at $37^{\circ} \mathrm{C}$. $50 \mu \mathrm{l}$ of stop solution was added to each well for quenching the reaction. Absorbance was read at $450 \mathrm{~nm}$ using Infinite 200Pro plate reader, Tecan, Switzerland.

\section{Statistical and Bioinformatics Analysis}

For proteomics data, multiple t-tests with Holm - Sidak corrections were used for assessing the statistical significance between groups. Only those proteins that showed differential regulation with fold change cut-off of two and $\mathrm{p} \leq 0.05$ were considered for further analysis.

For ELISA, unpaired t-test was used for assessing the statistical significance between groups $(\mathrm{p} \leq 0.05)$. Receiver Operating Curves (ROC) were also generated to assess sensitivity and specificity of the candidate proteins. All statistical analyses were carried out using GraphPad Prism version 6 (GraphPad Software, La Jolla California USA).

Principal component analysis (PCA) to check the variability in protein expression data between groups was performed using Array Track_HCA_PCA (Xu J et al., 2010). Heat maps were generated by Morpheus software (https://software.broadinstitute.org/morpheus/) using hierarchical clustering method.

\section{Results}

In a quest to decipher the pathophysiology of aneurysm formation and identify potential biomarkers for screening and differential diagnosis of intracranial aneurysm (IA), we performed iTRAQ-based quantitative proteomic analysis of IA wall tissue and serum samples of three groups of patients with a) unruptured aneurysm (T1) b) ruptured aneurysm (T2) and c) ruptured aneurysm with vasospasm (T3). Intracranial artery tissue samples and serum samples from subjects with no evidence of IA on autopsy or angiographic examination were used as controls $(\mathrm{C})$.

\section{Demographic data}


bioRxiv preprint doi: https://doi.org/10.1101/725473; this version posted August 9, 2019. The copyright holder for this preprint (which was not certified by peer review) is the author/funder, who has granted bioRxiv a license to display the preprint in perpetuity. It is made available under aCC-BY-NC-ND 4.0 International license.

For discovery phase, we used 20 tissue and 20 serum samples in the four groups: C, T1, T2 and T3. For validating potential biomarkers, we included a large cohort of 78 patients (13 control subjects, 13 patients ofT1 group, and 26 patients each from T2 and T3 groups. Demographic details of the subjects recruited in the study are provided in Table $\mathbf{1 .}$

\section{Overview of proteomics data}

In the past few years, quantitative proteomic analysis using isobaric mass tags has become the method of choice to compare proteomes of multiple physiological conditions. Here, we used iTRAQ, one such robust isobaric tagging method for quantitative proteomics of IA. To improve the depth and breadth of the study, we used both serum and tissue samples of IA.

A total of 937 proteins were identified following tissue analysis. From serum samples, we identified 294 proteins. 152 proteins were commonly identified in tissue and serum samples. Detailed information of the identified proteins in tissue and serum samples is provided in Supplementary Table 1 and 2 respectively.

Principal Component Analysis of both tissue and serum data (Fig. 2) showed a clear separation between the test groups and controls. While unruptured aneurysm (T1) samples clustered closer to the control group (C), ruptured aneurysms, both with and without vasospasm (T2 and T3), clustered on the same plane. However, we could observe complete separation between them. 


\begin{tabular}{|c|c|c|c|c|c|c|c|c|c|c|c|c|}
\hline \multirow{3}{*}{\begin{tabular}{|c|}
$\begin{array}{c}\text { Study } \\
\text { Groups }\end{array}$ \\
Phase \\
Type of \\
samples
\end{tabular}} & \multicolumn{3}{|c|}{$\begin{array}{l}\text { Contol group } \\
\text { (C) }\end{array}$} & \multicolumn{3}{|c|}{$\begin{array}{c}\text { Patients with unruptured aneurysm } \\
\text { (T1) }\end{array}$} & \multicolumn{3}{|c|}{$\begin{array}{l}\text { Patients with ruptured aneurysm } \\
\text { without vasospasm (T2) }\end{array}$} & \multicolumn{3}{|c|}{$\begin{array}{c}\text { Patients with ruptured aneurysm with } \\
\text { vasospasm (T3) }\end{array}$} \\
\hline & \multicolumn{2}{|c|}{ Discovery Phase } & \multirow{2}{*}{$\begin{array}{c}\begin{array}{c}\text { Validation } \\
\text { Phase }\end{array} \\
\text { Serum } \\
\text { samples }\end{array}$} & \multicolumn{2}{|c|}{ Discovery Phase } & \multirow{2}{*}{$\begin{array}{c}\begin{array}{c}\text { Validation } \\
\text { Phase }\end{array} \\
\text { Serum } \\
\text { samples }\end{array}$} & \multicolumn{2}{|c|}{ Discovery Phase } & \multirow{2}{*}{$\begin{array}{c}\begin{array}{c}\text { Validation } \\
\text { Phase }\end{array} \\
\text { Serum } \\
\text { samples }\end{array}$} & \multicolumn{2}{|c|}{ Discovery Phase } & \multirow{2}{*}{$\begin{array}{c}\begin{array}{c}\text { Validation } \\
\text { Phase }\end{array} \\
\text { Serum } \\
\text { samples }\end{array}$} \\
\hline & $\begin{array}{c}\text { Tissue } \\
\text { samples }\end{array}$ & $\begin{array}{c}\text { Serum } \\
\text { samples }\end{array}$ & & $\begin{array}{c}\text { Tissue } \\
\text { samples }\end{array}$ & $\begin{array}{c}\text { Serum } \\
\text { samples }\end{array}$ & & $\begin{array}{c}\text { Tissue } \\
\text { samples }\end{array}$ & $\begin{array}{c}\text { Serum } \\
\text { samples }\end{array}$ & & $\begin{array}{c}\text { Tissue } \\
\text { samples }\end{array}$ & $\begin{array}{c}\text { Serum } \\
\text { samples }\end{array}$ & \\
\hline Sample size & $\mathrm{n}=5$ & $\mathrm{n}=5$ & $\mathrm{n}=13$ & $\mathrm{n}=5$ & $\mathrm{n}=5$ & $\mathrm{n}=13$ & $\mathrm{n}=5$ & $\mathrm{n}=26$ & $\mathrm{n}=5$ & $\mathrm{n}=5$ & $\mathrm{n}=5$ & $\mathrm{n}=26$ \\
\hline $\begin{array}{c}\text { Age } \\
(\text { Mean } \pm \text { SD })\end{array}$ & $31 \pm 11$ & $51 \pm 8$ & $43 \pm 9$ & $44 \pm 16$ & $49 \pm 7$ & $39 \pm 11$ & $44 \pm 15$ & $49 \pm 5$ & $52 \pm 13$ & $43 \pm 11$ & $46 \pm 8$ & $50 \pm 8$ \\
\hline Sex (M:F) & $5: 0$ & $4: 1$ & $8: 5$ & $2: 3$ & $2: 3$ & $7: 6$ & $2: 3$ & $2: 3$ & $11: 15$ & $2: 3$ & $2: 3$ & $11: 15$ \\
\hline
\end{tabular}

Values are mean $\pm S D$ or number of patients

Table 1: Demographic Data

(M= Male; F= Female, $\mathrm{SD}=$ Standard Deviation) 


\section{A}

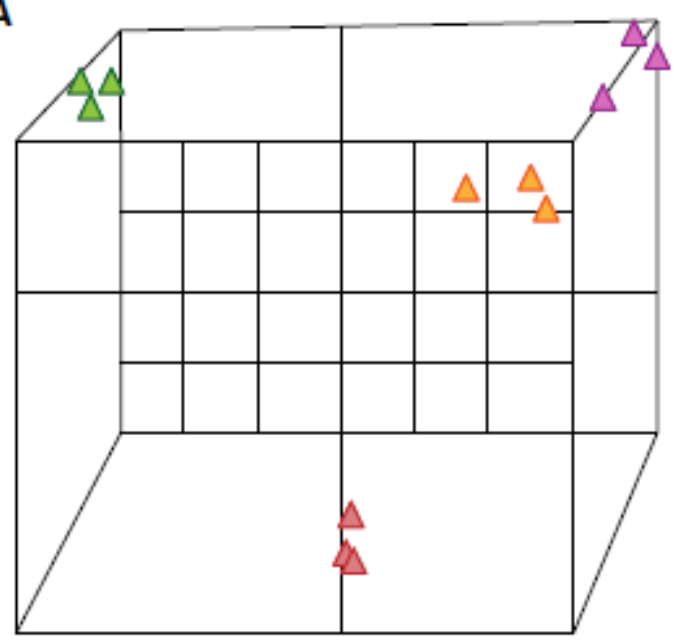

B

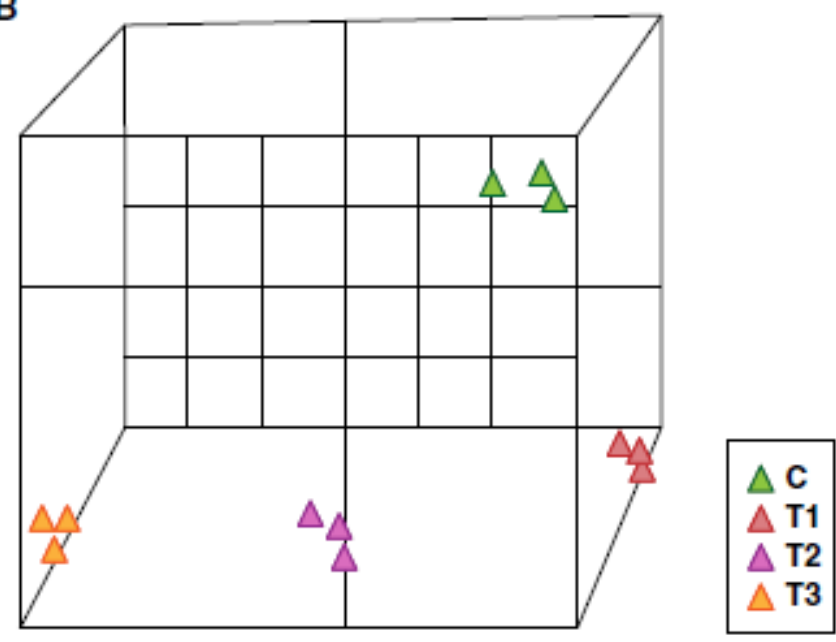

Figure 2: Principal Component Analysis. (A)Tissue Proteomics Data; (B) Serum Proteomics Data

We employed unsupervised clustering to identify molecular signatures associated with the clinical subsets of this study (Fig. 3). We observed that the three clinical subsets were molecularly differentiated in both tissue (Fig. 3A) and serum (Fig. 3B) samples. Further, several molecules were found to be common in the signatures of tissue and serum. These molecules are described in the next sections. 
A

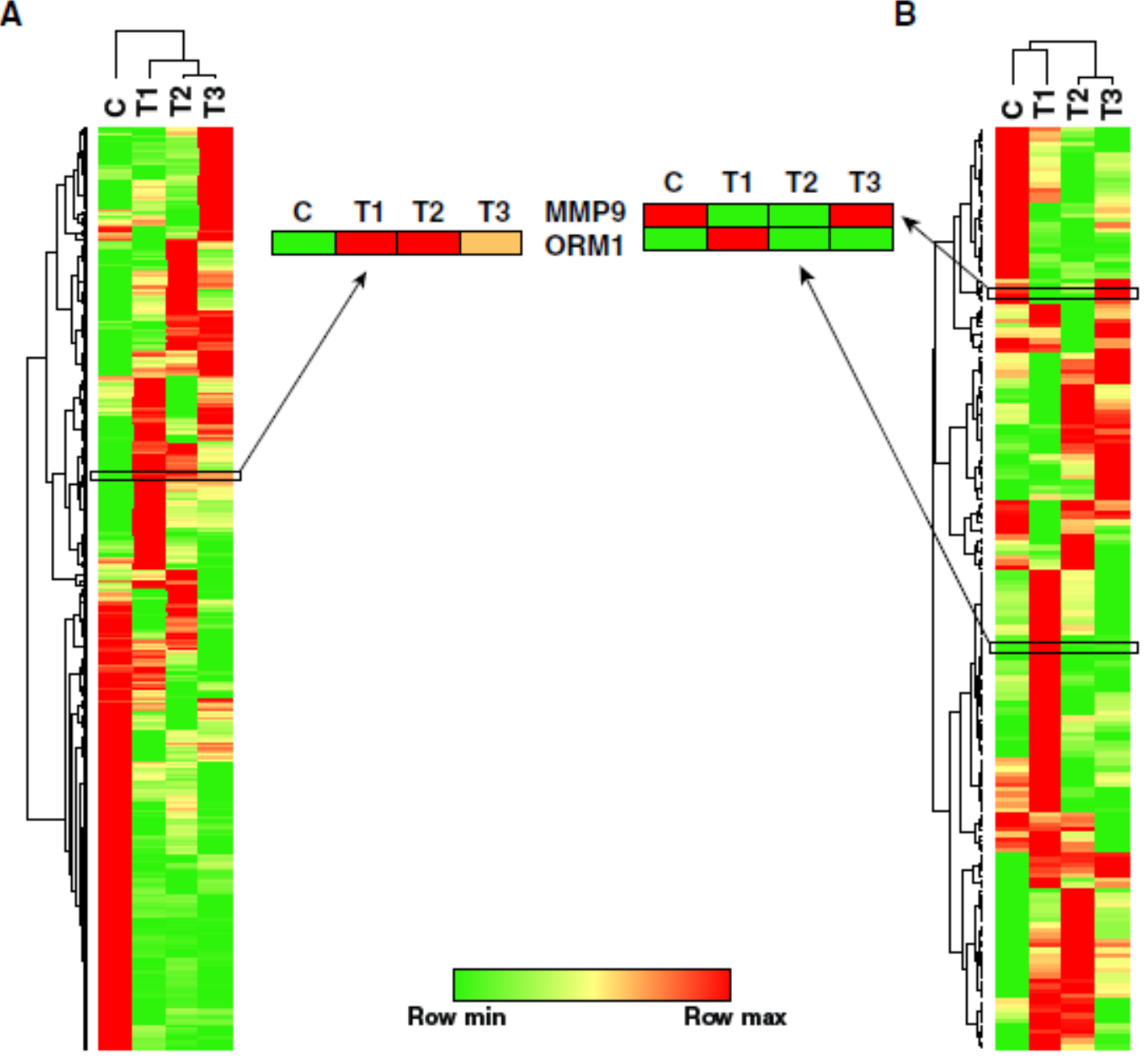

Figure 3: Heat map depicting molecular signatures associated with clinical subsets of patients with IA in (A) Tissue samples; (B) Serum samples

\section{Pathophysiology of aneurysm formation}

To identify the molecular events that lead to the formation of IA, we studied the differentially regulated proteins in the IA tissue and serum samples of unruptured aneurysm-patients in comparison to healthy controls (T1/C). We identified 139 dysregulated proteins in tissue samples, 62 of which were upregulated and 77 were downregulated. In serum samples, 48 proteins were differentially expressed, out of which 30 proteins were overexpressed and 18 were downregulated.

Commonly dysregulated proteins between tissue and serum included $\alpha$-1-acid glycoprotein 1 (ORM1), SAA2-SAA4 protein, $\alpha$-1-antitrypsin (SERPINA1), serotransferrin (TF), apolipoprotein A-I (APOA1), transgelin-2 (TAGLN2), cytoplasmic actin (ACTG1), collagen alpha-1(XVIII) (COL18A1) and peroxiredoxin-1 (PRDX1).

Earlier studies have shown that inflammatory pathways and activation of the complement cascade are important factors during aneurysm formation (Taylor et al., 2015, Turkmani et al., 2015). Numerous proteins known to be involved in inflammatory processes and 
bioRxiv preprint doi: https://doi.org/10.1101/725473; this version posted August 9, 2019. The copyright holder for this preprint (which was not certified by peer review) is the author/funder, who has granted bioRxiv a license to display the preprint in perpetuity. It is made available under aCC-BY-NC-ND 4.0 International license.

complement cascades were found to be overexpressed in both tissue and serum. Such proteins include $\alpha$-2-macroglobulin (A2M) complement factor $\mathrm{H}(\mathrm{CFH})$, complement $\mathrm{C} 3(\mathrm{C} 3)$, complement C1q subcomponent (C1QC), complement C5 (C5), Azurocidin (AZU1), S100A4, and S100A9.

Thrombospondins are involved in maintaining the structure of vasculature by mediating cellto-cell and cell-to-matrix interactions (Resovi et al., 2014, Sherbet et al., 2011). Thrombospondin1 (THBS1) has been shown to contribute to the development of Abdominal Aortic Aneurysm (AAA) by causing vascular inflammation through regulation of migration and adhesion of mononuclear cells (Liu et al., 2015). Thrombospondin 4 (THBS4) is involved in local signaling in nervous system and also contributes to spinal sensitization and neuropathic pain state (Kim et al., 2012). Role of THBS4 in inducing AAA has been recently demonstrated (Palao et al., 2016). Our study, both THBS1 and THBS4 were overexpressed in tissue and serum respectively. Thus, thrombospondins may play a role in the formation of aneurysm.

\section{ORM1 is a potential screening biomarker for unruptured aneurysm}

ORM1 is a glycosylated protein that has the capacity to bind and transport basic and neutral molecules(Fournier et al., 2000). ORM1 is primarily synthesized by the liver but can also be produced in extrahepatic sites (Luo et al., 2015). ORM1 is an acute phase inflammatory protein which also plays a role in injury induced angiogenesis (Ligresti et al., 2012). In the present study, ORM1 was found to be 22 fold overexpressed in IA tissue and 9 fold upregulated in serum and thus was selected as a candidate molecule for validation.

ELISA-based validation of ORM1 was carried out in serum samples of patients with unruptured aneurysms $(\mathrm{n}=13)$ and controls $(\mathrm{n}=13)$. We observed that levels of ORM1 were significantly higher $(\mathrm{p}=0.004)$ in serum of unruptured aneurysm as compared to controls. The area under the curve (AUC) was found to be 0.78 with sensitivity and specificity of $76.92 \%$ and $81.92 \%$, respectively (Fig. 4). Thus, ORM1 may be a potential biomarker for population screening of IA.

\section{Molecular mechanisms underlying aneurysmal rupture}

A significantly high number of patients with IA suffer from aneurysmal rupture every year. Comparing protein expression profiles of the samples with ruptured aneurysms with unruptured aneurysms is likely to provide an insight into molecular mechanisms underlying IA rupture. We identified42 differentially regulated proteins in tissues amples, out of which 28 were found to be upregulated and 14 were found to be downregulated. We could identify 37 differentially expressed proteins in serum samples, 10 proteins were overexpressed while 27 were found to be downregulated.

Chronic inflammation in aneurysm rupture has been associated in earlier studies (Hashimoto et al., 2006, Hudson et al., 2013). We observed overexpression of proteins related to inflammatory pathways in both tissue and serum samples. CRP was found to be upregulated in our study which has been demonstrated to be associated with an increase in size of AAA and its rupture (Turner et al., 2015, Vainas et al., 2003). Similarly, there was overexpression of SAA1 protein which could lead to aneurysmal rupture (Webb et al., 2015).

\section{Proteomic aberrations leading to vasospasm}


Development of vasospasm is seen to be detrimental to favorable prognosis post-aneurysmal rupture (Findlay et al., 2016). Proteins that play a role in the formation of vasospasm may be employed as potential prognostic biomarkers. To identify such molecules, we compared protein expression in tissue and serum samples of patients with ruptured aneurysm with vasospasm and ruptured aneurysm without vasospasm (T3/T2). We identified 33 differentially regulated proteins in tissue samples, out of which 13 were found to be upregulated, while 20 were downregulated. While in serum samples, 36 proteins were found to be differentially expressed out of which 20 were overexpressed and 16 were showing downregulated expression.

A

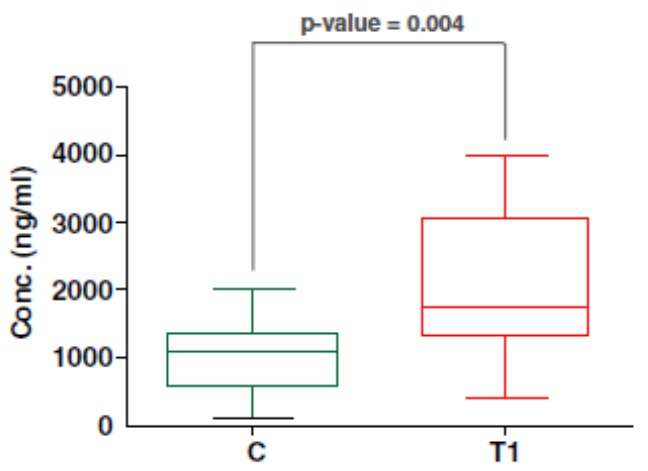

C

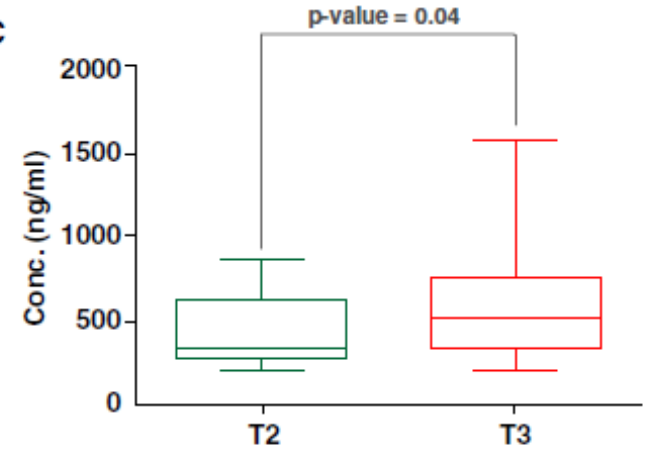

B

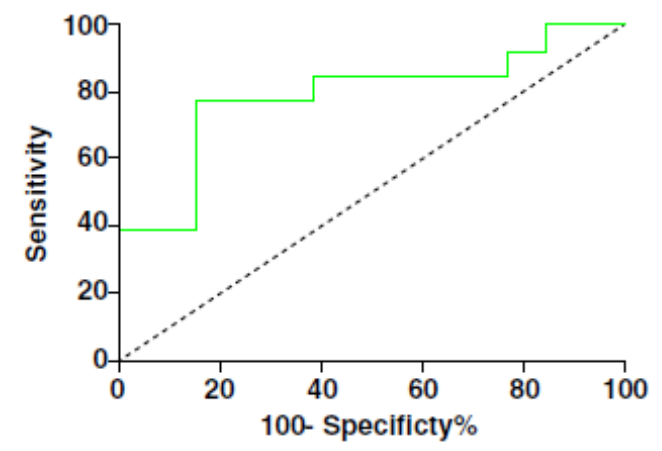

D

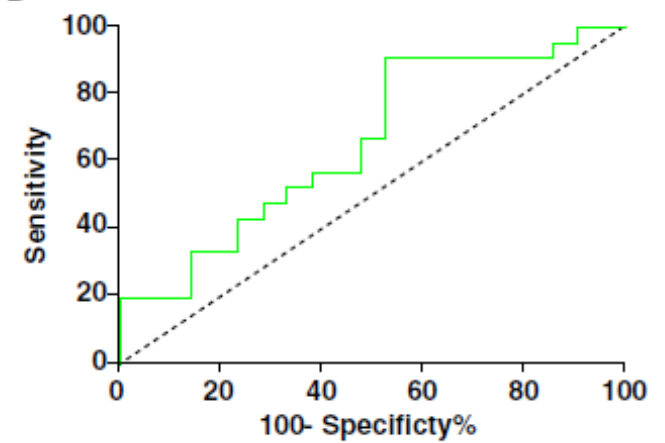

Figure 4: Estimation of ORM1 and MMP9 expression by ELISA. (A) Box plots depicting the difference in the expression level of ORM1 in patients with unruptured aneurysms compared to controls and (C) MMP9 in patients with ruptured aneurysms without vasospasm compared to ruptured aneurysm with vasospasm. (B) Receiver operating curve showing the specificity and sensitivity for ORM1 and (D) MMP9

To the best of our knowledge, this is the first proteomic study that compares differential expression of proteins in ruptured aneurysm with vasospasm and ruptured aneurysm without vasospasm. Superoxide has been reported to be associated with vasospasm (Suzuki et al. 1994; Mori, Nagata et al. 2001).We observed overexpression of protein Cytochrome b-245 light chain (CYBA) in tissue data. CYBA is known to associate with NOX3 to form a functional NADPH oxidase, which leads to generation of superoxide (Ueno, Takeya et al. 2005).

We also observed overexpression of proteins related to oxidative stress in patients with cerebral vasospasm. We found Myeloperoxidase (MPO) to be upregulated in tissue samples 
bioRxiv preprint doi: https://doi.org/10.1101/725473; this version posted August 9, 2019. The copyright holder for this preprint (which was not certified by peer review) is the author/funder, who has granted bioRxiv a license to display the preprint in perpetuity. It is made available under aCC-BY-NC-ND 4.0 International license.

which has been previously found to be associated with acute ischemic stroke (Cojocaru et al., 2010). Monoamine oxidase A (MAOA) was also found to be overexpressed. This protein has been demonstrated to oxidize biogenic amines such as norepinephrine and 5hydroxytryptamine causing oxidative stress (Youdim et al., 1984). In serum data, we observed elevated expression of peroxiredoxin-2 (PRDX2). This protein is related to oxidative stress and was found markedly elevated in the brain extracellular fluid in patients with acute ischemic stroke (Dayon et al., 2011).

\section{MMP9 is a potential biomarker for vasospasm}

MMPs are a family of extracellular and membrane-bound proteases capable of degrading or proteolytically modifying the ECM through interactions with collagenases, laminins and proteoglycans (Löffek et al., 2011). MMP9 is a type IV collagenase that is involved in the cleavage of a variety of substrates on the cell membrane and extracellular matrix. MMP9 was found to be 13.4 fold upregulated in serum samples of patients with ruptured aneurysm with vasospasm as compared to that without vasospasm and was selected as a candidate molecule for validation.

ELISA-based validation of MMP9 was carried out using serum samples from patients with ruptured aneurysm with vasospasm and without vasospasm ( $\mathrm{n}=26$ in each case). Levels of MMP9 were significantly higher (fold change $1.4, \mathrm{p}<0.05$ ) in case of patients with ruptured aneurysm with vasospasm as compared to patients with ruptured aneurysm without vasospasm. The area under the curve (AUC) was found to be 0.77 with sensitivity and specificity of $66.67 \%$ and $71.43 \%$, respectively (Fig. 4).

\section{Discussion}

Over the past decade, MS based quantitative proteomics has emerged as the method of choice to identify molecular signatures of disease and to optimize their management. In succession to the same, a number of studies following MS based analysis from literature have provided new subset of protein biomarkers with possible therapeutic targets for IA (Jiang et al., 2018, Wang et al., 2015, Wang et al., 2016, Xu et al., 2015). Presently, there is no molecular study to our knowledge, depicting the differential expression of the proteins between three subgroups of patients with IA. Thus, to decode possible causative proteins and to understand the pathophysiology of aneurysm formation, rupture and the progression to vasospasm, mass spectrometry based analysis was performed. We analyzed aneurysm-tissue and serum samples of patients with IA using MS based quantitative proteomics. We chose to analyze both tissue and serum samples to look for the reflection of dysregulated tissue proteins (microenvironment of disease) in the serum samples (macroenvironment of disease). This would help us in identifying biomarkers in serum samples which is an easily accessible biofluid. This study has resulted in the identification of numerous clinically interesting proteins which may have significant contribution in the genesis and progression of the disease.

Despite being a dreadful complication of brain vasculature, the pathogenesis of IA formation remains poorly understood. Although the presence of IA is significant in general population (Vlak et al., 2011), we are still at loss in detecting such patients prior to aneurysm rupture. Thus, it is important to study the biology of aneurysm formation as it may decipher molecules that can serve as biomarkers for population screening. 
bioRxiv preprint doi: https://doi.org/10.1101/725473; this version posted August 9, 2019. The copyright holder for this preprint (which was not certified by peer review) is the author/funder, who has granted bioRxiv a license to display the preprint in perpetuity. It is made available under aCC-BY-NC-ND 4.0 International license.

We studied differential expression of proteins in tissue and serum samples of patients with unruptured aneurysm and compared it to those of control samples. There were molecules such as ORM1, SERPINA1 and SAA2 - SAA4, which were commonly overexpressed in both tissue and serum data. Largely these have a role in the inflammatory pathway and inflammation has been demonstrated as an important pathological factor for formation of IA (Chalouhi et al., 2012, Hosaka and Hoh et al., 2014).

In our study we found upregulation of Matrix metalloproteinase (MMP-2) in serum data. MMP-2 is known to cleave the components of the ECM. Upregulation of MMP2 has been reported earlier (Maradni et al., 2013). Further, Intercellular adhesion molecule 1 (ICAM1) is expressed on the endothelial cells. This protein binds to integrins and is involved in cell adhesion. ICAM1 was shown to promote experimental aortic aneurysms through recruitment of circulating leukocytes (Xu et al., 2016). In the present study (ICAM1) was also found to be 3.8 fold upregulated in serum data. Thus our findings are in concordance with the previous reports (Davis et al., 1993, Szekanecz et al., 1994).

Proteins that are crucial for organizing cytoskeleton and its maintenance were found to be down regulated e.g. myosin-11 (MYH11), filamin-A, (FLNA), actin, aortic smooth muscle (ACTA2), smoothelin (SMTN), $\alpha$-actinin-4 (ACTN4), Tropomyosin1 (TPM1), tubulin $\alpha-1 \mathrm{C}$ chain (TUBA1C), laminin subunit beta-2 (LAMB2) and $\alpha$-actinin-1 (ACTN1). They play a significant role in cell to cell communication, interaction and regulation of movement. Their altered expression may contribute to IA formation by diminishing the structural architecture of cerebral vasculature. Proteins related to actin cytoskeleton may result in reduced tensile stretch exerted by blood pressure, leading to formation of aneurysm. Filamin-A is an actin binding protein involved in cytoskeleton remodeling. It promotes mitosis by binding to cdc25C (Telles et al., 2011). It is known to promote cell motility and migration. Down regulated expression of this protein demonstrates impaired division and growth of cells. Downregulated expression of proteins laminin subunit beta-2 (LAMB2) and $\alpha$-actinin-1 (ACTN1) was observed in a recent study on IA (Wang et al., 2016). Further, we found proteins such as Nidogen 1 (NID1), Cadherin 2 (CDH2) and Multimerin 2 (MMRN-2) to be downregulated in serum samples. These proteins play important roles in cell adhesion and growth (Galvagni et al., 2017, Maitre and Heisenberg et al., 2013, Miosge et al., 2001). NID1 is a basement membrane glycoprotein which interacts with other components of basement membranes and plays a role in cell interactions with the extracellular matrix. Multimerin 2 (MMRN2) is an ECM glycoprotein that is involved in angiogenesis and growth. Cadherins protect the cells from mechanical shear and stress and its deficiency may result in the loss of the protective ability against wall shear stress (WSS). WSS has been reported to play a role in the formation of IA (Chatziprodromou et al., 2007). Down regulation of the proteins related to cytoskeleton have also been reported in AAA formation (Modrego et al., 2012). This could explain the thinning of muscular layer of the intracranial vessel wall at the site of aneurysm formation.

Quantitative proteomic profiling of IA tissue and serum samples in patients with unruptured aneurysm when compared to controls enabled the identification of ORM1 as a potential biomarker for aneurysm formation. ELISA - based validation of ORM1 also confirmed its upregulation in serum of patients with unruptured aneurysm as compared to controls. ORM1 plays an important role in injury induced angiogenesis (Ligresti et al., 2012). At the site of vascular injury, endothelial cells on the luminal side are persuaded by TNF- $\alpha$ (secreted from macrophages) to secrete ORM1. ORM1 negatively inhibits the TNF- $\alpha$ at the site of injury acting as an anti-inflammatory protein. At the same time it induces angiogenesis. A well- 
bioRxiv preprint doi: https://doi.org/10.1101/725473; this version posted August 9,2019. The copyright holder for this preprint (which was not certified by peer review) is the author/funder, who has granted bioRxiv a license to display the preprint in perpetuity. It is made available under aCC-BY-NC-ND 4.0 International license.

known pathophysiological consequence of injury induced angiogenesis is that it increases permeability of intercellular endothelial cell junctions leading to edema and extensive injury to the surrounding tissue (Weis and Cheresh et al., 2005). Thus, ORM1 may play a role in aneurysm formation by inducing angiogenesis at the site of intimal injury that may progressively damage the vessel wall tissue (Fig. 5).

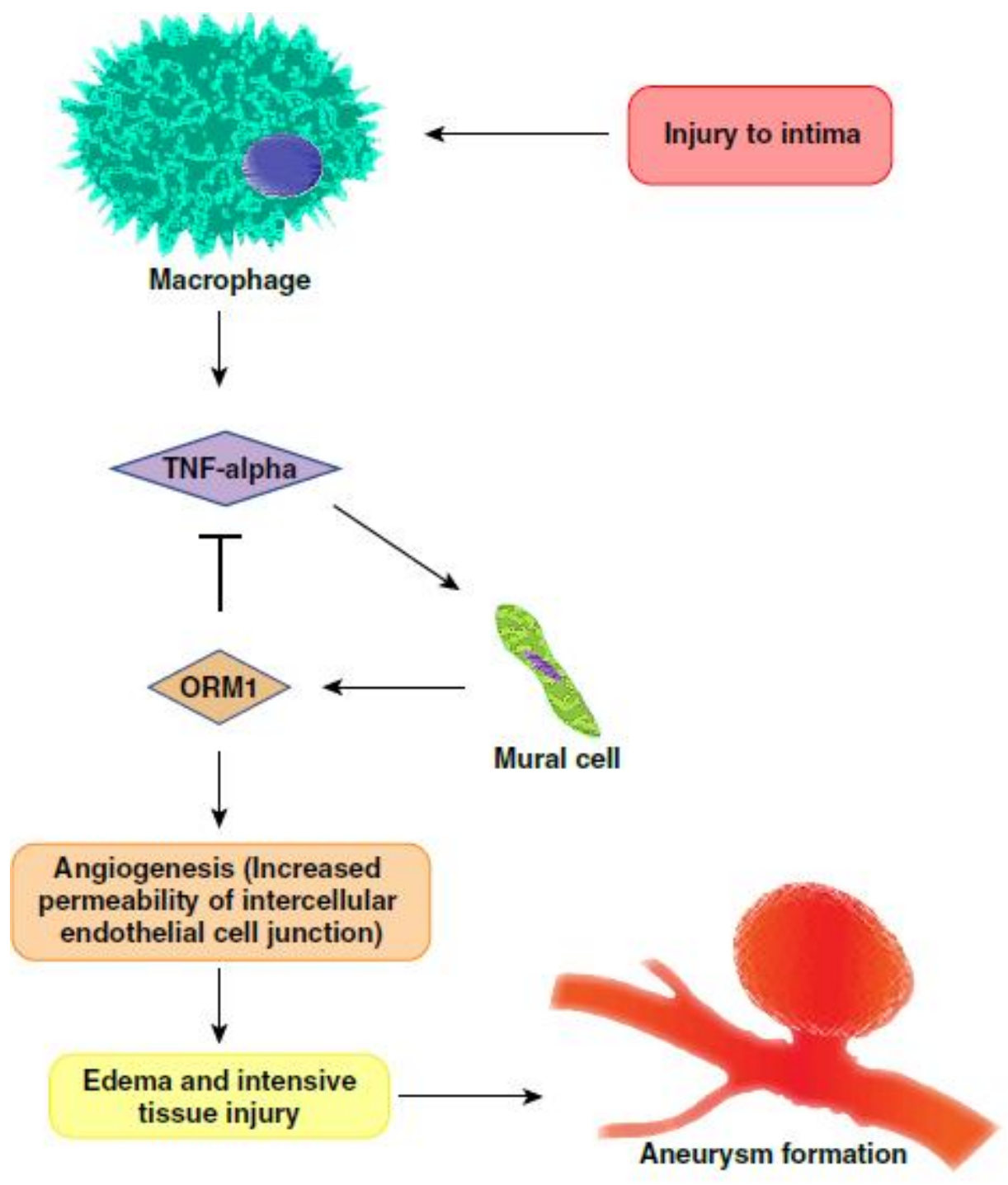

Figure 5: Potential mechanism of aneurysm formation through ORM1

There has been lot of enthusiasm in trying to understand how aneurysms formed in the cerebral vasculature eventually progress to rupture. It is intriguing why only few of the aneurysm rupture and most of them do not. To understand the biology of aneurysmal rupture, we studied differential expression of proteins in tissue and serum samples of patients with ruptured aneurysm and compared it to those with unruptured aneurysm. We observed over expression of Cathepsin B (CTSB, a lysosomal cysteine protease) in the tissue samples. It is possible that an increased activity of CTSB in the tissue samples may contribute to aneurysm progression through caspase induced apoptosis of Vascular Smooth Muscle Cells (VSMCs), as supported by previous reports (Guo et al., 2016, Aoki et al., 2008). Interestingly, we also observed upregulation of Cystatin B (CSTB, a cysteine protease inhibitor) in the tissue samples. A positive association of cystatins and abdominal aneurysm size has been shown 
bioRxiv preprint doi: https://doi.org/10.1101/725473; this version posted August 9, 2019. The copyright holder for this preprint (which was not certified by peer review) is the author/funder, who has granted bioRxiv a license to display the preprint in perpetuity. It is made available under aCC-BY-NC-ND 4.0 International license.

earlier (Wang et al., 2018). Our observation regarding the overexpression of fibrinogens (FGA, FGB and FGG) in the tissue samples is in good agreement with the report of AlBarjaset al. (2006), in which an increased level of fibrinogens was shown as a marker for aneurysm progression in AAA (Al-Barjas et al., 2006). Various proteins involved in maintaining vascular integrity and haemostatic balance in the cell including Microfibrillarassociated protein 4 (MFAP4), Decorin (DCN), Tropomyosin family proteins (TPM1, TPM2 and TPM4) along with F-actin-capping protein (CAPZA1) were found to be upregulated in the tissue samples, deregulation of which was found to be associated with aneurysm formation (Modrego et al., 2012).

On comparing the protein expression profiles of patients with ruptured aneurysm with and without vasospasm (T3/T2), we observed overexpression of AZU1 in the tissue samples. AZU1, an inflammatory cascade protein, is a component of neutrophil azurophilic granules and is implicated in proteolysis, apoptosis and phagocytic neutrophil oxygen independent killing (Soehnlein and Lindbom et al., 2009, Watorek et al., 2003). AZU1 is expressed in endothelial cells favoring contraction and increased endothelial permeability (Gautam et al., 2001). Narrowing of blood vessels which lead to cerebral vasospasm is characterized by prolonged abnormal contraction of VSMCs (Chaichana et al., 2010, Findlay et al., 1991, Ladner et al., 2013). Thus, an increased expression of AZU1 points to the fact that contraction of blood vessel may lead to cerebral vasospasm. S100A8 and S100A9 are the calcium binding proteins, which are known to play an important role in the regulation of inflammatory processes and immune response. Overexpression of these proteins also indicates the importance of inflammation in the development of vasospasm. Proteins related to cell adhesion and remodeling of the actin cytoskeleton such as integrin family proteins (ITGB3, ITGA2B and ITGB3), neutrophil defensin 1 (DEFA1), myeloblastin (PRTN3) and LTF (lactotransferrin) were found to be upregulated in patients with vasospasm. Blocking of integrins by their receptor antagonist GRGDSP has been shown to prevent vasospasm in earlier studies (Pradilla et al., 2004), which is correlated well with our finding.

Lysosomal related glycoprotein (LAMP1) and Transforming growth factor-beta-induced protein (TGFBI) were found to be overexpressed in serum samples of patients with cerebral vasospasm in the present study. LAMP1and cathepsins activate the caspase cascades that induce apoptosis in the endothelia lining the intima (Haka et al., 2016, Li et al., 1998). Apoptosis in the endothelium results in its detachment which exposes the collagen of the internal elastic lamina, which promotes platelet adherence and thrombus formation (Smith et al., 1985). Damage to endothelial cells also leads to reduction in nitric oxide production which demolishes the balance of vascular tone(Hino et al., 1996). This exposed arterial state results in direct contact of SMCs with vasoactive agents, such as ATP in the blood stream, which causes constriction of vessel wall (You et al., 1997). All these events may result in further narrowing of lumen resulting in cerebral vasospasm. TGFBI acts as a ligand recognition sequence for many integrins. This protein plays a role in cell-collagen interactions. Integrins play a role in altering calcium dynamics and phenotypic modulation of VSMCs (Balasubramanian et al., 2007, Qin et al., 2001). Thus, dysregulated expression of TGFBI may result in altered calcium dynamics leading to vasospasm.

Proteins involved in degradation of ECM such as matrix metalloproteinase (MMP9) were found to be significantly upregulated in serum data. One of the distinguishing features of cerebral vasospasm is prolonged contraction of the SMCs. Actin cytoskeleton of SMCs has a dynamic structure that plays an integral role in regulating the development of mechanical tension leading to contraction/dilation of smooth muscle tissues. Messed up actin 
polymerization has been linked with vasospasm in human saphenous vein (Hocking et al., 2016). In the present study, downregulation of proteins related to cytoskeleton remodeling such as ACTA2, TPM2 and MFAP4, demonstrates their role in the development of vasospasm. Neuroserpin (SERPINI1), an inhibitor of tissue plasminogen activator (tPA) provides protection against cerebral vasospasm by preventing $\mathrm{N}$-methyl-D-aspartic acidinduced neurotoxicity, which results in reducing tPA-mediated inflammation and disruption of the blood-brain barrier (BBB) (Gelderblom et al., 2013, Lebeurrier et al., 2005, Rodriguez et al., 2008). Thus, downregulated expression of this protein in our study demonstrates its significance in pathology of cerebral vasospasm.

Quantitative proteomic profiling enabled the identification of MMP9 as a potential prognostic biomarker for vasospasm formation and was validated on a larger cohort of patients using ELISA. MMP9, a matrix metalloproteinase has been implicated in the pathophysiology of blood brain barrier (BBB) disruption and cerebral edema (Obermeieret al., 2013, Turner and Sharp et al., 2016). The mechanism is complex, but on disruption of BBB, there is leakage of the inflammatory mediators which leads to arterial dysregulation due to leukocyte migration. This blockage in the artery may lead to its narrowing, resulting in vasospasm. Further, in a mouse model, protective role of minocycline, an inhibitor of MMP9, for cerebral vasospasm was demonstrated recently (Vellimana et al., 2017). Overall, it can be concluded that MMP9 has the potential to be used as a prognostic biomarker as well as a therapeutic target.

There are some limitations to the current study. We had a small sample size of patients in discovery phase. This was due to the difficulty in obtaining tissue samples of aneurysm wall. However, validation was done in a larger cohort based on sample size calculation. Nonetheless, it would be prudent to carry out further studies using a larger patient population. Although we have identified ORM1 and MMP9 as potential biomarkers, they need to be tested in a larger, geographically distinct cohort of patients to determine their diagnostic potential.

In spite of these variations, this study provides the first whole proteome characterization of the entire spectra of the disease in IA- tissue - and serum samples. This study indicates multiple proteins that may have a role in the pathogenesis of aneurysm formation, rupture and subsequent development of cerebral vasospasm. Findings from this study could lead to better diagnostic capabilities and therapeutic interventions.

\section{Acknowledgements}

The authors thank the patients and family members for their participation in the study. We would like to express our greatest gratitude to Late Dr. K.K. Mukherjee and Late Dr. V. K. Grover for their invaluable guidance and support for the conduct of the study.

\section{Competing interests}

The authors declare that they have no competing interests.

\section{Funding}

We thank the Department of Science \& Technology (DST), Chandigarh. 


\section{References}

Al-Barjas HS, Ariens R, Grant P, Scott JA. Raised plasma fibrinogen concentration in patients with abdominal aortic aneurysm. Angiology. 2006 Oct-Nov;57(5):607-14.

Archavlis E, Carvi Y Nievas M. Cerebral vasospasm: a review of current developments in drug therapy and research. journal of Pharmaceutical Technology and Drug Research. 2013 2013;2(1).

Balasubramanian L, Ahmed A, Lo CM, Sham JS, Yip KP. Integrin-mediated mechanotransduction in renal vascular smooth muscle cells: activation of calcium sparks. Am J Physiol Regul Integr Comp Physiol. 2007 Oct;293(4):R1586-94.

Chaichana KL, Pradilla G, Huang J, Tamargo RJ. Role of inflammation (leukocyte-endothelial cell interactions) in vasospasm after subarachnoid hemorrhage. World Neurosurg. 2010 Jan;73(1):22-41.

Chalouhi N, Ali MS, Jabbour PM, Tjoumakaris SI, Gonzalez LF, et al. Biology of Intracranial Aneurysms: Role of Inflammation. Journal of Cerebral Blood Flow \& Metabolism. 2012;32(9):165976.

Chatziprodromou I, Tricoli A, Poulikakos D, Ventikos Y. Haemodynamics and wall remodelling of a growing cerebral aneurysm: a computational model. J Biomech. 2007;40(2):412-26.

Chen S, Li Q, Wu H, Krafft PR, Wang Z, Zhang JH. The Harmful Effects of Subarachnoid Hemorrhage on Extracerebral Organs. BioMed Research International. 2014;2014:12.

Cojocaru IM, Cojocaru M, Iliescu I, Botnaru L, Gurban CV, et al. Plasma myeloperoxidase levels in patients with acute ischemic stroke. Rom J Intern Med. 2010;48(1):101-4.

Connolly ES, Jr., Fiore AJ, Winfree CJ, Prestigiacoma CJ, Goldman JE, Solomon RA. Elastin degradation in the superficial temporal arteries of patients with intracranial aneurysms reflects changes in plasma elastase. Neurosurgery. 1997 May;40(5):903-8; discussion 8-9.

Davis CA, 3rd, Pearce WH, Haines GK, Shah M, Koch AE. Increased ICAM-1 expression in aortic disease. J Vasc Surg. 1993 Nov;18(5):875-80.

Dayon L, Turck N, García-Berrocoso T, Walter N, Burkhard PR, et al. Brain Extracellular Fluid Protein Changes in Acute Stroke Patients. Journal of Proteome Research. 2011 2011/03/04;10(3):1043-51.

Deeb SJ, Tyanova S, Hummel M, Schmidt-Supprian M, Cox J, Mann M. Machine Learning-based Classification of Diffuse Large B-cell Lymphoma Patients by Their Protein Expression Profiles. Mol Cell Proteomics. 2015 Nov;14(11):2947-60. 
Findlay JM, Macdonald RL, Weir BK. Current concepts of pathophysiology and management of cerebral vasospasm following aneurysmal subarachnoid hemorrhage. Cerebrovasc Brain Metab Rev. 1991 Winter;3(4):336-61.

Findlay JM, Nisar J, Darsaut T. Cerebral Vasospasm: A Review. Can J Neurol Sci. 2016 Jan;43(1):15-32.

Fournier T, Medjoubi NN, Porquet D. Alpha-1-acid glycoprotein. Biochim Biophys Acta. 2000 Oct $18 ; 1482(1-2): 157-71$.

Frosen J, Piippo A, Paetau A, Kangasniemi M, Niemela M, et al. Remodeling of saccular cerebral artery aneurysm wall is associated with rupture: histological analysis of 24 unruptured and 42 ruptured cases. Stroke. 2004 Oct;35(10):2287-93.

Gaetani P, Tartara F, Tancioni F, Rodriguez y Baena R, Casari E, et al. Deficiency of total collagen content and of deoxypyridinoline in intracranial aneurysm walls. FEBS Lett. 1997 Mar 10;404(23):303-6.

Galvagni F, Nardi F, Spiga O, Trezza A, Tarticchio G, et al. Dissecting the CD93-Multimerin 2 interaction involved in cell adhesion and migration of the activated endothelium. Matrix Biol. 2017 Dec;64:112-27.

Gautam N, Olofsson AM, Herwald H, Iversen LF, Lundgren-Akerlund E, et al. Heparin-binding protein (HBP/CAP37): a missing link in neutrophil-evoked alteration of vascular permeability. Nat Med. 2001 Oct;7(10):1123-7.

Gelderblom M, Neumann M, Ludewig P, Bernreuther C, Krasemann S, et al. Deficiency in serine protease inhibitor neuroserpin exacerbates ischemic brain injury by increased postischemic inflammation. PLoS One. 2013;8(5):e63118.

Haka AS, Barbosa-Lorenzi VC, Lee HJ, Falcone DJ, Hudis CA, et al. Exocytosis of macrophage lysosomes leads to digestion of apoptotic adipocytes and foam cell formation. J Lipid Res. 2016 Jun;57(6):980-92.

Hino A, Tokuyama Y, Weir B, Takeda J, Yano H, et al. Changes in endothelial nitric oxide synthase mRNA during vasospasm after subarachnoid hemorrhage in monkeys. Neurosurgery. 1996 Sep;39(3):562-7; discussion 7-8.

Hocking KM, Putumbaka G, Wise ES, Cheung-Flynn J, Brophy CM, Komalavilas P. Papaverine Prevents Vasospasm by Regulation of Myosin Light Chain Phosphorylation and Actin Polymerization in Human Saphenous Vein. PLoS One. 2016;11(5):e0154460. 
Hosaka K, Hoh BL. Inflammation and cerebral aneurysms. Transl Stroke Res. 2014 Apr;5(2):190-8.

Jiang P, Wu J, Chen X, Ning B, Liu Q, et al. Quantitative proteomics analysis of differentially expressed proteins in ruptured and unruptured cerebral aneurysms by iTRAQ. J Proteomics. 2018 Jun $30 ; 182: 45-52$.

Kim DS, Li KW, Boroujerdi A, Peter Yu Y, Zhou CY, et al. Thrombospondin-4 contributes to spinal sensitization and neuropathic pain states. J Neurosci. 2012 Jun 27;32(26):8977-87.

Ladner TR, Zuckerman SL, Mocco J. Genetics of cerebral vasospasm. Neurol Res Int. 2013;2013:291895.

Lebeurrier N, Liot G, Lopez-Atalaya JP, Orset C, Fernandez-Monreal M, et al. The brain-specific tissue-type plasminogen activator inhibitor, neuroserpin, protects neurons against excitotoxicity both in vitro and in vivo. Mol Cell Neurosci. 2005 Dec;30(4):552-8.

Li H, Zhu H, Xu CJ, Yuan J. Cleavage of BID by caspase 8 mediates the mitochondrial damage in the Fas pathway of apoptosis. Cell. 1998 Aug 21;94(4):491-501.

Ligresti G, Aplin AC, Dunn BE, Morishita A, Nicosia RF. The acute phase reactant orosomucoid-1 is a bimodal regulator of angiogenesis with time- and context-dependent inhibitory and stimulatory properties. PLoS One. 2012;7(8):e41387.

Löffek S, Schilling O, Franzke C-W. Biological role of matrix metalloproteinases: a critical balance. European Respiratory Journal. 2011;38(1):191-208.

Luo Z, Lei H, Sun Y, Liu X, Su DF. Orosomucoid, an acute response protein with multiple modulating activities. J Physiol Biochem. 2015 Jun;71(2):329-40.

Maitre JL, Heisenberg CP. Three functions of cadherins in cell adhesion. Curr Biol. 2013 Jul 22;23(14):R626-33.

Maradni A, Khoshnevisan A, Mousavi SH, Emamirazavi SH, Noruzijavidan A. Role of matrix metalloproteinases (MMPs) and MMP inhibitors on intracranial aneurysms: a review article. Med J Islam Repub Iran. 2013 Nov;27(4):249-54.

Miosge N, Holzhausen S, Zelent C, Sprysch P, Herken R. Nidogen-1 and nidogen-2 are found in basement membranes during human embryonic development. Histochem J. 2001 Sep-Oct;33(910):523-30. 
Modrego J, López-Farré AJ, Martínez-López I, Muela M, Macaya C, et al. Expression of cytoskeleton and energetic metabolism-related proteins at human abdominal aortic aneurysm sites. Journal of Vascular Surgery. 2012;55(4):1124-33.

Nakajima N, Nagahiro S, Sano T, Satomi J, Satoh K. Phenotypic modulation of smooth muscle cells in human cerebral aneurysmal walls. Acta Neuropathol. 2000 Nov;100(5):475-80.

Pradilla G, Wang PP, Legnani FG, Ogata L, Dietsch GN, Tamargo RJ. Prevention of vasospasm by anti-CD11/CD18 monoclonal antibody therapy following subarachnoid hemorrhage in rabbits. J Neurosurg. 2004 Jul;101(1):88-92.

Qin H, Ishiwata T, Asano G. Effects of the extracellular matrix on lumican expression in rat aortic smooth muscle cells in vitro. J Pathol. 2001 Dec;195(5):604-8.

Rajesh BJ, Sandhyamani S, Bhattacharya RN. Clinico-pathological study of cerebral aneurysms. Neurol India. 2004 Mar;52(1):82-6.

Resovi A, Pinessi D, Chiorino G, Taraboletti G. Current understanding of the thrombospondin-1 interactome. Matrix Biology. 2014 2014/07/01/;37:83-91.

Rodriguez C, Martinez-Gonzalez J, Raposo B, Alcudia JF, Guadall A, Badimon L. Regulation of lysyl oxidase in vascular cells: lysyl oxidase as a new player in cardiovascular diseases. Cardiovasc Res. 2008 Jul 1;79(1):7-13.

Sherbet GV. 10 - Thrombospondins. In: Sherbet GV, editor. Growth Factors and Their Receptors in Cell Differentiation, Cancer and Cancer Therapy. London: Elsevier; 2011. p. 111-4.

Smith PK, Krohn RI, Hermanson GT, Mallia AK, Gartner FH, et al. Measurement of protein using bicinchoninic acid. Anal Biochem. 1985 Oct;150(1):76-85.

Smith RR, Clower BR, Grotendorst GM, Yabuno N, Cruse JM. Arterial Wall Changes in Early Human Vasospasm. Neurosurgery. 1985;16(2):171-6.

Soehnlein O, Lindbom L. Neutrophil-derived azurocidin alarms the immune system. J Leukoc Biol. 2009 Mar;85(3):344-51.

Szekanecz Z, Shah MR, Pearce WH, Koch AE. Intercellular adhesion molecule-1 (ICAM-1) expression and soluble ICAM-1 (sICAM-1) production by cytokine-activated human aortic endothelial cells: a possible role for ICAM-1 and sICAM-1 in atherosclerotic aortic aneurysms. Clin Exp Immunol. 1994 Nov;98(2):337-43. 
Taylor BES, Appelboom G, Zilinyi R, Goodman A, Chapel D, et al. Role of the complement cascade in cerebral aneurysm formation, growth, and rupture. Neuroimmunology and Neuroinflammation. 2015;2(2):93-101.

Telles E, Gurjar M, Ganti K, Gupta D, Dalal SN. Filamin A stimulates cdc25C function and promotes entry into mitosis. Cell Cycle. 2011 Mar 1;10(5):776-82.

Turkmani AH, Edwards NJ, Chen PR. The role of inflammation in cerebral aneurysms. Neuroimmunology and Neuroinflammation. 2015;2(2):102-6.

Vellimana AK, Zhou ML, Singh I, Aum DJ, Nelson JW, et al. Minocycline protects against delayed cerebral ischemia after subarachnoid hemorrhage via matrix metalloproteinase-9 inhibition. Ann Clin Transl Neurol. 2017 Dec;4(12):865-76.

Vlak MH, Algra A, Brandenburg R, Rinkel GJ. Prevalence of unruptured intracranial aneurysms, with emphasis on sex, age, comorbidity, country, and time period: a systematic review and meta-analysis. Lancet Neurol. 2011 Jul;10(7):626-36.

Wang C, Qu B, Wang Z, Ju J, Wang Y, et al. Proteomic identification of differentially expressed proteins in vascular wall of patients with ruptured intracranial aneurysms. Atherosclerosis. 2015 Feb;238(2):201-6.

Wang J, Yu L, Huang X, Wang Y, Zhao J. Comparative proteome analysis of saccular intracranial aneurysms with iTRAQ quantitative proteomics. J Proteomics. 2016 Jan 1;130:120-8.

Wang Y, Liu C-L, Lindholt JS, Shi G-P, Zhang J. Plasma Cystatin B Association With Abdominal Aortic Aneurysms and Need for Later Surgical Repair: A Sub-study of the VIVA Trial. European Journal of Vascular and Endovascular Surgery. 2018 2018/12/01/;56(6):826-32.

Watorek W. Azurocidin -- inactive serine proteinase homolog acting as a multifunctional inflammatory mediator. Acta Biochim Pol. 2003;50(3):743-52.

Weis SM, Cheresh DA. Pathophysiological consequences of VEGF-induced vascular permeability. Nature. 2005 Sep 22;437(7058):497-504.

Xu B, Iida Y, Xuan H, Li S, Fujimura N, et al. IP019. ICAM-1 Promotes Experimental Aortic Aneurysms Through Recruitment of Circulating Leukocytes. Journal of Vascular Surgery. 2016;63(6):62S-3S.

Xu J, Ma F, Yan W, Qiao S, Xu S, et al. Identification of the soluble form of tyrosine kinase receptor Axl as a potential biomarker for intracranial aneurysm rupture. BMC Neurol. 2015 Mar 5;15:23. 
You J, Johnson TD, Childres WF, R. M. Bryan J. Endothelial-mediated dilations of rat middle cerebral arteries by ATP and ADP. American Journal of Physiology-Heart and Circulatory Physiology. 1997;273(3):H1472-H7.

Youdim MBH, Finberg JBM, Kuhn DM, Wolf WA. The role of monoamine oxidase A in the metabolism and function of noradrenaline and serotonin. In: Paton W, Mitchell J, Turner P, editors. IUPHAR 9th International Congress of Pharmacology: Proceedings Volume 2. London: Macmillan Education UK; 1984. p. 203-9.

Zoerle T, Lombardo A, Colombo A, Longhi L, Zanier ER, et al. Intracranial pressure after subarachnoid hemorrhage. Crit Care Med. 2015 Jan;43(1):168-76. 